\title{
Polish Combatants' Association in Canada and Its Support for Solidarity Movement and Polish Refugees in 1980s
}

The aim of this paper is to present support rendered by Polish veterans in Canada for the "Polish cause" in 1980s - i.e. during the brief "carnival of Solidarity" and subsequent period of martial law which resulted in massive wave of emigrants leaving the country between 1981-1987. The scope of engagement of Polish WWII veterans settled in Canada into various forms of assistance for the Solidarity movement in Poland (demonstrations, petitions, fundraising) and combatants' attitude towards the new wave of political and economic immigrants arriving from Poland to the Country of Maple Leaf in 1980s. is presented on the basis of archival documents (by-laws, regulations, financial reports, internal correspondence) and press releases ("SPK w Kanadzie" - quarterly magazine of the Polish Combatants Association in Canada).

Keywords: veterans, refugees, self-exiled people, Solidarity Trade Union

Multifold activities taken up by Polish veterans who settled in Canada after WWII so far have been described only fragmentarily and selectively. Most of the publications fall into two categories: veterans' recollections from war period and the first years spent in Canada $^{2}$ and commemorative texts ${ }^{3}$, describing combatants'

1 Contact: m.paluszkiewicz-misiaczek@uj.edu.pl

2 Among publications on the subject the following should be mentioned: a volume of memories of forty-five Polish war refugees (among whom only thirty enjoyed the veteran status) - published in English and Polish: K. Patalas ed. (1996), Przez boje, przez znoje, przez trud. Kombatanckie losy, Winnipeg: Stowarzyszenie Polskich Kombatantów w Kanadzie; English version: K. Patalas ed. (2004), Providence Watching. Journeys from Wartorn Poland to the Canadian Prairies, Winnipeg: University of Manitoba Press; a small collection of correspondence: J. W Broda. ed. (1971), Weterańskie listy, Ottawa: Bilioteczka Kieszonkowa

3 Main publications documenting the activities of the Polish Combatant Association in Canada are: E. Soltys, B. Heydenkorn (1992) Trwanie $w$ walce - kulturowa analiza SPK $w$ Kanadzie, Toronto: 
patriotic involvement, usually taken up within the framework of local branches of Stowarzyszenie Polskich Kombatantów SPK (Polish Combatants' Association PCA) scattered throughout the country. The authors of such texts aimed mainly at stressing sacrifice and merits of particular people or groups, describing their contribution to emigration collective identity building. Few texts provide comprehensive historical analysis regarding the issue of the Polish WWII veterans' settlement in Canada and their involvement in social and political life of Polish group in that country ${ }^{4}$. Such situation may have resulted from the fact that Polish researchers working in Canada were careful when taking up certain problems, perceived as potentially contentious ${ }^{5}$, while scientists working in Poland, could not carry out in depth research before 1989 due to the censorship regulations and limited access to the archives or press sources.

The aim of this paper is to present so far neglected fragment of the history of Polish veterans in Canada, namely their support rendered for the "Polish cause" in 1980s - i.e. during the brief "carnival of Solidarity" and subsequent period of martial law which resulted in massive wave of emigrants leaving the country between $1981-1987^{6}$. On the basis of archival documents (by-laws, regulations, financial

Canadian Polish Research Institute; Czterdzieści lat w stużbie idei Stowarzyszenia Polskich Kombatantów. SPK w Kanadzie, Koło nr 6 Edmonton (1988), Edmonton: SPK w Kanadzie; E. Soltys, K. Klimaszewski, M. Szczeciński (1997), Road to Freedom, Toronto: Polish Combatants Association in Canada.

${ }^{4}$ On settlement of Polish veterans in Canada see: M. Thornton (2000), The Domestic and International Dimensions of the Resettlement of the Polish Ex-Servicemen in Canada, 1943-1948, Queenston, Ontario: The Edwin Mellen Press. Problems of veterans who settled in Canada after WWII were also partly discussed within the scope of A. Reczyńska (1997), Piętno wojny. Polonia kanadyjska wobec polskich problemów lat 1939-1945, Kraków: Nomos. As Canadian section of Polish Combatants Association has belonged to the World Federation of Polish Combatants' Associations, general and comparative information about veterans' activities and problems can be found at: T. Kondracki (1996), Historia Stowarzyszenia Polskich Kombatantów w Wielkiej Brytanii, London: Zarząd Główny SPK w Wielkiej Brytanii; T. Kondracki (2007), Polskie organizacje kombatanckie w Wielkiej Brytanii w latach 1945-1948, Warszawa: "Neriton" - Instytut Historii PAN; M. Filek, R. Koperski (1992), Stowarzyszenie Polskich Kombatantów w Australii (1950-1992), Adelaide: Zarząd Krajowy Stowarzyszenia Polskich Kombatantów w Australii; L. Kędziora (2013), Polskie organizacje kombatanckie we Francji w latach 1945-1976, Warszawa: Difin; W. Leitgeber (1995), Polski Korpus Przysposobienia i Rozmieszczenia w świetle dokumentów brytyjskich in: Klimaszewicz L. (ed.), Mobilizacja uchodźctwa do walki politycznej 1945-1990, London: Polskie Towarzystwo Naukowe na Obczyźnie; P. Kardela (2015), Stowarzyszenie Polskich Kombatantów w Stanach Zjednoczonych w latach 1953-1990, OlsztynBiałystok: Oddział IPN w Białymstoku.

${ }^{5}$ Especially troubled relations between WWII veterans and members of Polish diaspora who had arrived to Canada in late $19^{\text {th }}$ and early $20^{\text {th }}$ century.

${ }^{6}$ Attitudes towards Solidarity movement among members of Polish diaspora (also WWII veterans) have been recently analysed by J. Wojdon (2013), Polonia Amerykańska a "Solidarność" w latach 1980-1989 and P. Polec (2013), Akceptacja i adaptacja do zmian: ruch "Solidarności" i solidarnościowi imigranci w społeczeństwie kanadyjskim i polsko-kanadyjskim w latach 1980-1991. Both articles in: P. Jaworski, Ł. Kamiński (ed.), Świat wobec Solidarności, Warszawa: IPN. In this publication there is also one text fully devoted to the undertakings of Polish veterans in America, see: P. Kardela (2013), Stowarzyszenie Polskich Kombatantów w Stanach Zjednoczonych wobec "Solidarności", in: P. Jaworski, Ł. Kamiński (ed.) Świat wobec... . 
reports, internal correspondence) and press releases ("SPK w Kanadzie" - quarterly magazine of the Polish Combatants Association in Canada) I try to present the scope of engagement of Polish WWII veterans settled in Canada into various forms of assistance for the Solidarity movement in Poland (demonstrations, petitions, fundraising) and their attitude towards the new wave of political and economic immigrants from Poland arriving to the Country of Maple Leaf in 1980s.

After WWII roughly 30000 Polish veterans settled in Canada. The first Polish soldiers (some Polish Navy officers and a few dozens of pilots) arrived in 1940, among 500 civilian refugees, mainly high-rank civil servants and their families. In spring 1941, they were joined by around 100 soldiers (so-called General Bronisław Duch Mission) whose aim was recruitment for the Polish Army ${ }^{7}$. In 1941-1943, the permit for temporary stay in Canada was also granted to approximately 600 military industry specialists (esp. aviation), military men among others ${ }^{8}$. After the end of WWII, in the wake of demobilization of the Polish Armed Forces in the West, the British authorities asked the other countries within the Commonwealth to accept Polish veterans. Throughout 1946 and 1947 the Dominion of Canada admitted 4257 soldiers selected from over 7,000 interested in immigration to that country ${ }^{9}$. The condition of admittance was signing a two-year contract to work in farming or forestry industries. In many cases Polish veterans replaced the German Prisoners of War (POWs) as well as the Japanese-Canadians placed for the period of the war in internment camps. Working conditions on the farms and in the forest camps were harsh and remuneration was considerably lower than the average wage for an unskilled labourer. Due to numerous protests and active operations of the newly established Canadian branch of Polish Combatants' Association, the first concessions were obtained. The veterans with two-year contracts were allowed to change their employers after the first year of the deal. It helped to improve, at least partially, the working and pay conditions. Additionally, the ex-soldiers with serious health problems (mainly TB) were granted permission to terminate their contract obligations before the due date ${ }^{10}$. The attempts to loosen the conditions were of utmost

7 A. Reczyńska (1997), Piętno wojny... , p. 99-100, 122-123.

${ }^{8}$ Brzeziński T. (1988), Forty Years among Poles in Canada, in: Heritage and the Future. Essays on Poles in Canada, Heydenkorn B. (ed.), Toronto: Canadian Polish Research Institute, p. 153, 154; Soltys E., Heydenkorn B. (1992), Trwanie $w$ walce. Kulturowa analiza SPK w Kanadzie. Toronto: Canadian Polish Research Institute, p. 10.

${ }^{9}$ Ibid., p. 10-11; S.P.K. w Kanadzie urodziło się we Włoszech. "SPK w Kanadzie” No. 4/40, Oct. 3, 1971, p.5.

${ }^{10}$ E. Soltys, B. Heydenkorn, Trwanie..., p. 13, 36-40; J. Ostrowski, Zarys historyczny Stowarzyszenia Polskich Kombatantów w Kanadzie, "SPK w Kanadzie” No. 2/74, April 1980, p. 9-10. About conditions of work on the farms and beginnings of life in Canada see: Cz. Jaroński. (1977), W walce z przeciwnościami, in: Heydenkorn B. (ed.) Pamiętniki imigrantów polskich w Kanadzie, Toronto: Canadian Polish Research Institute, pp. 61-88; J. Bauer (1979), The Youngest Soldier, in: Heydenkorn B. (ed.) Memoirs of Polish Immigrants in Canada, Toronto: Canadian Polish Research Institute, p. 4-14. 
importance, as only after the completion of the contract could a veteran enjoy the right to choose an employer and apply for permanent resident status in Canada.

At the end of 1940s, when the government in Ottawa gradually liberalized the regulations concerning the admittance of the displaced persons (DPs), further groups of Polish veterans reached Canada. Among them there were soldiers of the Polish Armed Forces in the West as well as the prisoners of war released from the German POW camps and some Polish Underground Army members who found themselves in Germany after the Warsaw Uprising or left Poland directly after the end of WWII. Those groups reached Canada through Italy, the Netherlands, the UK and/or the occupation zones in Germany. It is estimated that approximately 50000 Polish DPs were admitted by the Dominion of Canada by 1952 (a significant percentage of them were veterans) ${ }^{11}$. After 1956 , there were also cases of the ex-soldiers of the Polish Underground Army leaving for Canada directly from Poland ${ }^{12}$.

Polish veterans, just like vast majority of all immigrants had to overcome initial obstacles and difficulties connected with rebuilding life in a totally new environment. However, in the case of many combatants, settlement problems were often additionally coupled with the experience of war trauma. Many ex-soldiers suffered from TB and other health problems resulting either from years spent in Russian labour and German POW camps and/or from wounds sustained in combat. Very common, yet carefully concealed, was also the problem of alcohol abuse, as many veterans tried to soothe post traumatic stress disorder in this way. The Polish Combatants' Association which had been established in 1945 in Britain in order to help demobilised soldiers in this difficult process of transition into civil life, played invaluable role for continuation of comradeship and mutual aid, "promoting in every possible way the well-being of Polish ex-servicemen and women who decided to remain outside Poland"13.

Canadian section of the association was established in Italy by the members of the first group of veterans who decided to sign a two-year contract and were waiting for deployment overseas. In the very first months after the arrival to Canada small branches of Polish Combatants' Association sprang up in the towns and settlements located close to the places where the veterans were carrying out their contacts. By 1947 there were 20 local units of the association scattered throughout the territory of the whole country ${ }^{14}$. From the very beginning local centres of PCA combined activities aiming at betterment of the situation of veterans with active organizational,

11 A. Reczyńska, Piętno..., p. 227.

12 R. Kogler (1995), The Polish Community in Canada, in: Sołtys E., Kogler R. (ed.) Half a Century of Canadian Polish Congress, Toronto: Canadian Polish Research Institute, p. 303-304.

13 Polish Ex-Servicemen in Great Britain (1948?), London: Information and Advice Bureau of the Polish Combatants' Association, p. 12.

${ }_{14}$ Ostrowski J., Zarys historyczny Stowarzyszenia Polskich Kombatantów w Kanadzie, "SPK w Kanadzie", No. 4/72, October 1979, p. 10-11. 
educational and patriotic work. PCA leaders wanted to attain four major aims, outlined during the first general assembly of the organization held in Winnipeg in 1948. Among the issues enumerated as the most pressing by the veterans participating in the meeting there were: 1) continuation of the fight for freedom and territorial integrity of Poland; 2) fighting the communism as the new totalitarian regime constituting immense threat for all the free world; 3) rendering assistance in bringing to Canada and settling relatives of the combatants as well as other displaced people not willing to return to the communist Poland; 4) achieving unification of all the competing Polish organizations in Canada ${ }^{15}$. The last aim was partially achieved already in 1950, when Polish Combatants' Association joined the Canadian Polish Congress an umbrella organization aiming to represent various groups of Polish Canadians. Veterans were quite quickly elected to the executive board of CPC, and began to constitute an influential group in the organization and started shaping its policy ${ }^{16}$.

Veterans' organizational work was very efficient and PCA was rapidly developing in terms of membership and financial capacity throughout 1950s and 1960s ${ }^{17}$. In 1970s the organization consisted of approximately 30000 members, (26 320 men and 421 women) gathered in 20 local branches scattered throughout Canada. The association estimated cautiously value of its real estate and funds deposited in the banks as the sum of $400000 \$$. Yet, the influx of young people, i.e. children of combatants, who were also encouraged to join the association, was rather limited. Thus, at the turn of 1970s and 1980s the age composition of the organization was the following: below $40-10.7 \%$, between $40-65-61.1 \%$, over $65-28.2 \%{ }^{18}$.

The association formed the core of patriotic activism, with its members actively supporting Polish Government in Exile ${ }^{19}$. Combatants were also trying to follow the

15 The Canadian Polish Research Institute (CPRI) - collection not cataloqued, Stowarzyszenie Polskich Kombatantów (SPK), Okólnik referatu oświatowego SPK w Kanadzie, 3 October 1949; J.Ostrowski, Zarys historyczny Stowarzyszenia Polskich Kombatantów w Kanadzie, "SPK w Kanadzie" No. 3/75, July 1980, p. 10.

16 A. Reczyńska (1995), The Origins and the Beginnings of Canadian Polish Congress, in: Half a Century of Canadian Polish Congress, Sołtys E., Kogler R. K. (ed.), Toronto: Canadian Polish Research Institute, p. 29-30.

17 Reports from the meetings of the main board or from the general assemblies show that the governing body of the association as well as heads of particular branches were conducting sound financial policy, successfully investing funds obtained from membership fees, donations, various charitable ventures or business enterprises held at the premises of combatants' halls. See: CPRP, SPK, Komunikat Informacyjny Zarządu Głównego Stowarzyszenia Polskich Kombatantów Rok 1955; ibid., Sprawozdanie z Walnego Zjazdu Polskich Kombatantów. Lata 1979 - 1981. Construction or purchase of buildings which served as combatants' halls was possible thanks to money collections organized by the veterans, bank loans and money which belonged to the Second Corps which was transferred from Britain in 1953. See: Ostrowski J., Zarys historyczny Stowarzyszenia Polskich Kombatantów w Kanadzie, "SPK w Kanadzie” No. 2/86, April 1983, p. 15.

18 J. P. Kott, 1946-1981, “SPK w Kanadzie”, No. 1/81, January 1982, p. 8-9.

19 SPK - Historia Federacji, p. 91-92, http://parafiabradford.co.uk/SPK_history.pdf, [accessed: 02.04.2018]. 
situation in communist Poland, even though any contacts of PCA members, especially leaders, with representatives of communist government were strictly forbidden. Although ex-soldiers voiced their support for all sights of grass-roots anti-communist resistance which could be observed in Poland prior to 1980s, when the Independent and Self-Governing Trade Union Solidarność was born, veterans' circles initially observed its calls for democratic reforms with certain amount disbelief, suspicious whether such wave of resistance could really be born within the communists-ruled country. Nevertheless, they quickly began organizing economic assistance for the Union and its members, usually sent via the structures of the Roman Catholic Church. Combatants were also actively lobbying on behalf of Poland among Canadian politicians or people of influence. After the introduction of martial law in Poland on December 13, 1981 they also got involved in sponsorship of Polish refugees.

\section{Humanitarian aid and economic assistance for the Solidarity Movement}

In private combatants and other members of Polish diaspora in Canada were sending food and clothing parcels for the families and friends remaining in Poland from the very first years after the end of the $w^{20}{ }^{20}$. Particular branches of the association were also supporting various Polish benevolent institutions, for example the school for blind children in Laski ${ }^{21}$. At the end of 1970s, when Poland began to face serious shortages of the most basic products, economic assistance rendered by members of Polish community in Canada got more organized and consistent form. The leaders of Polish Combatants' Association issued a call to all branches of the organization to get involved in the action called "Bread for Poland Campaign", coordinated by the Canadian Polish Congress ${ }^{22}$. Unfortunately in the archives of PCA held by the Canadian Polish Research Institute there are no consistent financial reports which would allow to evaluate the full scope and range of veterans' involvement in the action. Nevertheless, on the basis of the reports from particular branches of the association published in organization's quarterly magazine "SPK w Kanadzie" it is clearly visible that combatants' donations were substantial. In the summary published in January 1982 one can read that until August 15, 1981 all branches of PCA in Canada collected 37800 Canadian dollars

${ }^{20}$ Pocket calendars issued by Polish Combatants' Association for the members of the organization provided information about the cheapest and most reliable ways to send money, food, medicines and clothing See: CPRI, Kalendarzyk Kombatanta, years: 1949, 1965, 1972, 1979.

${ }^{21}$ Sprawozdania Zjazdowe Kót - Koło SPK 1 - Thunder Bay, "SPK w Kanadzie", No. 2/78 April 1981, p. 21.

${ }_{22}$ Przed walnym Zjazdem, "SPK w Kanadzie", 2/78 kwiecień 1981 s. 3; Apel Kongresu Polonii Kanadyjskiej, "SPK w Kanadzie”, 2/78 kwiecień 1981, p. 4 
(CAD) for "Bread for Poland" fund ${ }^{23}$. Sums sent by particular branches depended on the number of active members and their organizational abilities. For example branch in Edmonton managed to gather 900 CAD under the heading "Bread for Poland" 24 , while branch in Calgary informed that it sent to the headquarters of the Canadian Polish Congress 3500 CAD for Polish workers ${ }^{25}$.

Some members of the Polish Combatants' Association had doubts concerning organization of the above mentioned action, fearing that the aid will not reach those who are really in need. They were voiced in the combatants' quarterly magazine by the president of Montreal branch: "Although we have no certainty that the help will reach those who are in need and despite conflicting opinions about the action, the President believes that we should fulfill our duty towards the Nation, rendering moral and financial support"26. Probably due to those reservations expressed by the activists doubting if assistance is going to reach the right recipients, in the next issue of "SPK w Kanadzie" K. Klimaszewski - member of the main board of Polish Combatants Association and Secretary of the Canadian Polish Congress presented in detail the results of the collection coordinated by CPC with participation of various Polish organizations in Canada, PCA included.

Table 1

Results of Collection “Aid for Poland - Food and Medical Supplies" on August 15, 1981.

\begin{tabular}{|l|l|}
\hline Money collected for food and medications & $400666 \$$ \\
\hline Value of medical supplies donated by pharmaceutical companies & $104000 \$$ \\
\hline Value of food purchased so far at wholesale prices and sent to Poland & $228000 \$$ \\
\hline Amounts and type of food sent to Poland & 82400 pounds \\
\hline Powdered milk & 2200 pounds \\
\hline Powdered chocolate & 124300 pounds \\
\hline Lard & 183000 pounds \\
\hline Canned meat &
\end{tabular}

Source: Komunikat Prasowy, “SPK w Kanadzie”, No. 2/82 April 1982, p. 5.

He also informed the readers that food purchased at the wholesale price was packed into 20-tone containers, shipped to Poland and reached Charity Board of Polish Episcopate (Komisja Charytatywna Episkopatu Polski) in Gdańsk Oliwa.

${ }^{23}$ Jan P. Kott, $1946-1981 \ldots$, p. 8-9.

${ }^{24}$ Sprawozdania Zjazdowe Kót - Koło SPK 6 - Edmonton, "SPK w Kanadzie”, No. 2/78 kwiecień 1981, p. 23.

${ }^{25}$ Sprawozdania Zjazdowe Kót - Koło SPK 6 - Calgary, "SPK w Kanadzie", 3/79 lipiec 1981, p. 27

${ }^{26} Z$ życia kót - Koło SPK 7 Montreal "SPK w Kanadzie”, No. 2/78 kwiecień 1981, p. 14; 
The Canadian Polish Congress received documents confirming that the shipment was picked up by the representatives of Charity Board and food would be distributed through the network of Roman Catholic parishes in Poland, while the medical supplies were channeled to a central depot managed by the Solidarity Labour Movement ${ }^{27}$.

Aid for Poland (food and medical supplies) was briefly suspended after the introduction of martial law on December 13, 1981. Yet, already on January 28, 1982 the Canadian Polish Congress managed to reestablish contacts with the Charity Board of Polish Episcopate and shipments of the most needed supplies were resumed. The main board of CPC announced in PCA quarterly that by April 1982 the overall sum of donations for Aid for Poland Fund (Fundusz Pomocy Polsce) reached 1200 000, 00 CAD (food, medical supplies, clothing and shoes). In subsequent years economic help was maintained, and what is important the amount of money gathered for that purpose did not decrease substantially ${ }^{28}$. It was stated in the report of the chairman of Polish Combatants' Association for the years 1981-1983, that as far as organization of collections for the purpose of sending material assistance to Poland was concerned, PCA decided to participate in the actions organized under the auspices of the Canadian Polish Congress, rather than organize some small scale events itself. Thus, particular branches were not obliged to send information about the exact amounts collected and transferred to CPC, yet rough estimations allowed veterans to have "the sense of well fulfilled duty"29.

\section{Information and lobbying campaigns}

The task to "...inform the free world about the true nature of the atheist communist regime imposed in Poland" ${ }^{30}$ was considered to be the basic duty of every member of Polish Combatants' Association from the moment the organization was established. Veterans never missed any opportunity to present the so called "Polish cause" during commemorative events (especially those organized for successive anniversaries of Katyń Massacre or Monte Cassino victory), official meetings or

${ }^{27}$ K. Klimaszewski, Zbiórka - Pomoc Polsce - Żywność i Leki, "SPK w Kanadzie”, No. 4/80, October 1981 p. 2.; J. Serge, Canadian Poles Fly Tones of Food to the Needy, "SPK w Kanadzie”, No. 1/81, January 1982, p. 18.

${ }^{28}$ Komunikat Prasowy, "SPK w Kanadzie”, 2/82, April 1982, p. 5. [reprint from “Toronto Star”]

${ }^{29}$ CPRI, SPK, Sprawozdanie Prezesa Głównego SPK w Kanadzie za kadencję 1981-1983, p. 6 in: Protokół XX-go Walnego Zjazdu Stowarzyszenia Polskich Kombatantów w Kanadzie, 21-23 maj 1983, Toronto, Ontario.

${ }^{30}$ CPRI, SPK, Protokół XX-go Walnego Zjazdu Stowarzyszenia Polskich Kombatantów w Kanadzie, 21-23 maj 1983, Toronto, Ontario, p. 12. 
celebrations, especially those held in cooperation with the Canadian Legion ${ }^{31}$ and/ or attended by various Canadian officials and people of influence.

At the turn of 1980 and 1981, being aware of mounting social and political tensions, leaders of PCA attempted to draw the attention of prominent Canadian politicians to the situation in Poland. They prepared two open letters addressed to the Ministers of the Crown and members of the Canadian Parliament. Their signatories pointed to "...the threat of the military intervention of the USSR and other countries of the Warsaw Pact" stressing that "the formation of the independent trade unions in Poland does not pose any threat to the security of its neighbors"32. Polish veterans also tried to warn about the possibility of "provocation" which could be "an excuse of a drastic action, which in turn may result in grave consequences" ${ }^{\prime 3}$, recalling the "shameful chapter of our modern history" and "sad lessons - East Germany - 1953, Hungary - 1956, Czechoslowakia - 1968, Afganistan - 197934. They called the leaders of "...this most democratic, free, progressive and liberal Nation (...) to lodge at the United Nations the strongest possible protest against the presence of massive military forces of Soviet Union poised all around the boundaries of Poland" 35 . Veterans also expressed hopes that "...repeated warnings addressed to the Soviet Union by Canada and other western powers will be given a serious consideration by the Soviet leaders" ${ }^{36}$. Fear of Russian invasion was profound among vast majority of the Polish veterans, especially ex-members of Polish Armed Forces in the West burdened with their memories of Russian invasion on Polish territory in September 1939 and subsequent deportations of Poles from the occupied areas. Combatants perceived potential soviet intervention as the most immediate threat. The authors of the appeal stressed that because of their status of ex-servicemen, "...having had the honor to fight, most of us under British command for the survival of freedom and democracy..." it was their sacred duty to defend "basic human rights of the Polish nation". The letters ended with the call for economic assistance for Poland devastated by 35 years of communist rule and the statement that Polish Combatants' Association had already got involved in the program of sending food and medical supplies organized under the auspices of the Canadian Polish Congress ${ }^{37}$.

${ }^{31}$ Veteran organization established after WWI in order to serve veterans and their families and promote remembrance. Since 1960 known as The Royal Canadian Legion. Its main aim is to provide assistance for Canadian veterans as well as serving members of Canadian Armed Forces and Royal Canadian Mounted Police (RCMP). See: Our History; http://www.legion.ca/who-we-are/what-we-do/ our-history, [Accessed: 22.07.2018].

${ }^{32}$ CPRI, SPK, Draft of an open letter to the Ministers of the Crown, Senators and Members of the House of Commons, 14.03.1981. The letter was published at "SPK w Kanadzie", No. 4/80, October 1981, p. 12-13.

${ }^{33}$ Ibid.

${ }^{34}$ CPRI, SPK, Open Letter to the Members of the Legislature, 1981. [spelling original].

${ }^{35}$ Ibid.

${ }^{36}$ CPRI, SPK, Draft of an open letter to the Ministers of the Crown...

${ }^{37}$ Ibid. 
After the introduction of Martial Law in Poland president of Combatants' Association Mieczysław Szczeciński issued on December 22, 1981 a special appeal to all branches asking its members to get involved in all types of demonstrations or campaigns aiming at informing the Canadian society about the plight of Poland. He also urged them to organize meetings with members of federal and provincial parliaments, activists of Canadian Legion or trade unions, write letters to the press and try to reach other mass media. In contacts with all of the above mentioned people and institutions members of PCA were to ask them to demand repeal of martial law, release of Lech Walesa and other imprisoned activists, organization of free and democratic elections in Poland as well as to lobby for sending more economic aid to the oppressed country. Polish veterans were also advised to stress in contacts with Canadian officials the measures which should be introduced in relations with the USRR: imposing economic sanctions, breaking economic ties and depriving this country of its place in the $\mathrm{UN}^{38}$.

When informing about the actions taken up by the Canadian government after December 13, 1981 Polish Combatants' Association decided to take up diplomatic stance. Thus, in quarterly "SPK w Kanadzie" there is no mention about the statement made by Prime Minister Pierre Trudeau in the House of Commons on December 18, 1981, in which he presented his concerns about the situation in Poland, yet argued that "...if martial law is a way to avoid civil war and Soviet intervention then I cannot say it is all bad" 39 . This real-politic comment was received by the vast majority of Polish Canadians with indignation and disbelief. Yet, in order to avoid any further controversies, veterans decided to quote in their magazine only the statement made by the Prime Minister to the Canadian Polish community, in which he "...extended to Polish Canadians his deepest sympathy, in the most difficult period for the Polish people" and informed about substantial grant awarded to the Canadian Polish Congress to assist its relief efforts ${ }^{40}$.

Similarly there was no direct criticism of Trudeau's words in the open letter to the Prime Minister issued on December 21, 1981 by Mieczysław Szczeciński on behalf of Polish veterans - “...the first post-war immigrants to this free country (...) grateful for that privilege, [believing that] Canada has had no reason to complain about our contribution to the Canadian life and society." ${ }^{41}$ PCA's president diplomatically requested “...the Government of Canada protest strongly and firmly to the government of the Polish People's Republic against the suppression of human

${ }^{38}$ Do wszystkich Kół SPK, "SPK w Kanadzie", No. 2/82, April 1982, p. 4-5.

${ }^{39}$ J. English (2009), Just Watch Me. The Life of Pierre Elliot Trudeau: 1968-2000, Toronto: Alfred Knopf Canada, p. 579.

40 Statement by the Prime Minister to the Canadian Polish Community, Christmas 1981, "SPK w Kanadzie", no. 2/82, April 1982, p. 4.

${ }^{41}$ The Right Honorable Pierre E. Trudeau, "SPK w Kanadzie", No. 2/82, April 1982, p. 4. 
rights and freedom, demand that martial law in Poland be removed immediately and that proper conditions be created to enable the present crisis in Poland be solved without any outside direct or indirect intervention" ${ }^{\text {"2 }}$. He also voiced the expectation that "Canada should demonstrate before the whole world that she is true defender of human rights and democracy." ${ }^{43}$ There was no open criticism of the actions taken or not taken so far.

Nevertheless, the fact that Polish veterans living in Canada were deeply aggrieved by Trudeau's words is visible from the fragment of an open letter to Ronald Regan dated February 1, 1982, issued by the very same President of Polish Combatants Association in Canada. One can read there the following, meaningful statements: "Only the United States of America and you, Mister President, have evaluated the situation in Poland in proper perspective. (...) Your prompt decisions and your action represent the hope that justice will prevail and Poland will be free again". The letter ends with straightforward words: "Our hope (...) depends on you and the United States of America"44.

In the articles published in combatants' quarterly magazine in 1982, there are also certain hints confirming that the problem of Canadian government's reaction to the introduction of martial law in Poland was discussed during the meeting of the Prime Minister with the representatives of the Polish Canadian community organized at the beginning of 1982. The talks were summed up by Canadian Foreign and Defense Policy Secretariat as "...frank exchange of views on the subject of the situation in Poland" ${ }^{\prime 4}$. Polish combatants stated that during the meeting Canadian politicians "...heard quite harsh words of criticism concerning the standpoint of the Canadian Government towards Martial Law in Poland", yet the critical remarks were delivered "with a lot of tact (...) in impeccable English"46.

\section{Attitude towards massive wave of emigration from Poland}

Canadian authorities responded to the crisis in Poland and the imposition of martial law introducing special measures to assist Polish citizens wishing to emigrate to the Country of Maple Leaf both because of political persecution and economic deprivation. Between 1981-1983 immigration rules for Poles were substantially eased. Thanks to that a large number of Polish citizens already in Canada,

\footnotetext{
${ }^{42}$ Ibid.

${ }^{43}$ Ibid.

${ }^{44}$ Open Letter to His Excellency Ronald Regan, "SPK w Kanadzie", no. 2/82, April 1982, p. 6.

${ }_{45}$ Statement of D.P. Wightman, Senior Officer, Foreign and Defence Policy Secretariat, "SPK w Kanadzie", No. 3/83, July 1982, p. 5.

${ }^{46}$ Z działalności Zarządu Głównego SPK od 13 grudnia 1981. "SPK w Kanadzie", No. 2/82, April 1982, p. 9-10.
} 
holders of visitor or student visas, were permitted to remain in the country for at least a year. Within that time they could apply for permanent residence. Additionally, processing of applications of people sponsored by Canadian citizens or permanent residents was sped up. In late 1982 authorities in Ottawa also managed to convince Polish communist government to let Polish citizens participate in the Canadian immigration program designed for a designated class of political prisoners and oppressed persons ${ }^{47}$. In the first two years of its operation approximately 600 detainees and their family members were given exit permits by the Polish authorities and issued entry visas by the Canadian embassy in Warsaw. The program was renewed on one-year basis until 1988, yet in the subsequent years the number of Poles leaving their motherland on the basis of this special measure securing release of political prisoners was much lower ${ }^{48}$. It has been estimated that thanks to special immigration rules introduced for Polish citizens between 1981-1984 approximately 20000 Poles entered Canada ${ }^{49}$.

Polish community in Canada was lobbing for the introduction of the above mentioned special immigration procedures, especially to alleviate the situation of asylum seekers in Austria. For example, on December 23, 1981 during the meeting between the members of the Canadian Polish Congress and the Secretary of State for External Affairs Mark R McGauigan the issue of acceptance of Polish refugees was mentioned. CPC presented the standpoint that "... emigrants from Poland, who found themselves in various European countries and especially in Austria ... should be considered, under present conditions Political Refugees [emphasis from the author], unless they express their will to return to Poland now. To all those, immigration and settlement in Canada should be made accessible on humanitarian basis" ${ }^{\prime 0}$. However, in the face of increasing number of Poles wishing to emigrate to Canada, finding private sponsors became most pressing thing. President of Polish Combatants Association issued an open letter to all branches of the organization. He reported in it that during the talks held with the Canadian authorities concerning the issue of enlarging the number of Polish immigrants entering this country, Canadian Minister of immigration expressed his astonishment that such a small number of Polish people recognized as self-exiled was sponsored by Polish Canadians and various social organizations grouping them. The minister pointed to great involvement of the Canadian society on behalf of the "boat people"s1, contrasting it

\footnotetext{
${ }^{47}$ N. Kelley, M. J. Trebilcock (2010), Making of the Mosaic. A History of Canadian Immigration Policy, Toronto: University of Toronto Press, p. 399.

${ }^{48}$ G.E. Dirks (1995), Controversy and Complexity: Canadian Immigration Policy During the 1980s, Monteral: McGill-Queen's University Press, p. 70.

${ }^{49}$ Ibid., 71

${ }^{50}$ J. Kaszuba, K.F. Klimaszewski, Notes on the Meeting, "SPK w Kanadzie", No. 2/82, April 1982, p. 6.

${ }^{51}$ At the turn of 1979 and 1980, almost 60000 immigrants from Southeast Asia, mainly Vietnam, were admitted to Canada on humanitarian basis in relation with huge refugee crises. 26000
} 
with the meager number of 169 Polish refugees who received similar private guarantees until April 1982. Veterans' representatives agreed that this number was absolutely too low, especially that such ratio, in comparison with the size of Polish group in Canada estimated as 350 000, would mean that one sponsored person fell to 2060 Poles already settled in that country. Authorities of Polish Combatants' Association called each branch to sponsor one person or family, guaranteeing "material assistance" i.e. costs of accommodation, food and clothing for the period of one year. It was suggested that when deciding whom to accept, priority should be given to Polish combatants either from Polish Underground Army, Polish Forces in the West or Dywizja Kościuszkowska ${ }^{52}$, as such people, due to their age and health problems would have small chances to immigrate individually ${ }^{53}$.

In the statement issued during the 20th General Congress of Polish Combatants' Association held between 21-23 May 1993 in Toronto, its participants, “... shocked by brutal and bloody liquidation of the Solidarity movement and imprisonment of its democratic leaders" voiced solidarity and unity with Poles remaining in the country and with their fight for freedom of Poland and the basic human rights. They also expressed readiness to support all kinds of the efforts of the Canadian Polish Congress to provide help for the massive wave of Polish immigrants and refugees from the "enslaved country". The statement ended with an appeal to the members of the organization "to render them all kind of assistance and wholehearted help during the difficult beginnings in the new environment" 54 .

The results of the surveys prepared before the general assemblies of Polish Combatants' Association held in 1983, 1985 and 1987 provide interesting data about the number of immigrants sponsored by particular branches of the association and decisions whether to continue this form of activism in the future. In the reports from the 20th assembly covering the years 1981-1983 there is no collective summary concerning sponsoring or support for the refugees. Yet, in the reports prepared by particular branches one can come across information about certain efforts in this respect. Thus, Vice-President of PCA for East Canada informed that members of the association managed to convince the authorities of Academie Ste Anne in Rowdon, Quebec (a college run by Catholic Nuns) to accept two young Polish girls for a two-year long secretarial course free of charge, offering

were sponsored by the Canadian Government, while the remaining 34000 were sponsored by private groups or individual citizens. See: Canadian Response to the "Boat People" Refugee Crisis, http://www. thecanadianencyclopedia.ca [Accessed: 02.04.2018].

${ }^{52}$ Dywizja Kościuszkowska (The 1st Tadeusz Koścuszko Infantry Division) - Polish military units subordinate to Moscow, composed mainly of the Poles who had been deported to the USSR between 1939-1941, released from prisons and labor camps on the basis of Sikorski-Mayski Agreement, yet did not manage to join the units formed by General Anders (subordinate to British command).

${ }^{53}$ M. Szczepański, List do kót, SPK w Kanadzie", no. 2/82, April 1982, p. 5.

${ }^{54}$ CPRI, SPK, Protokół XX-go Walnego Zjazdu Stowarzyszenia Polskich Kombatantów w Kanadzie, 21-23 maj 1983, Toronto, Ontario, p. 12. 
Table 2

Number of immigrants sponsored by particular branches of Polish Combatants' Association.

\begin{tabular}{|c|c|c|c|c|}
\hline \multirow{2}{*}{$\begin{array}{c}\text { Branch of Polish } \\
\text { Combatants' } \\
\text { Association }\end{array}$} & \multicolumn{2}{|c|}{$\begin{array}{c}\text { Number of ordinary } \\
\text { members }\end{array}$} & \multirow{2}{*}{$\begin{array}{c}\text { Number of } \\
\text { immigrants } \\
\text { sponsored between } \\
1983-1985 / \\
\text { willingness to } \\
\text { sponsor in the } \\
\text { future }\end{array}$} & \multirow{2}{*}{$\begin{array}{c}\text { Number of } \\
\text { immigrants } \\
\text { sponsored between } \\
\text { 1985-1987/ } \\
\text { willingness to } \\
\text { sponsor in the } \\
\text { future }\end{array}$} \\
\hline & 1983-1985 & 1985-1987 & & \\
\hline $\begin{array}{l}\text { Branch No } 1 . \\
\text { Thunder Bay, } \\
\text { Ontario }\end{array}$ & 256 & 260 & $4 /$ no & $0 /$ no answer \\
\hline $\begin{array}{l}\text { Branch No } 2 . \\
\text { London, Ontario }\end{array}$ & 150 & 155 & $8 /$ no answer & No data / no answer \\
\hline $\begin{array}{l}\text { Branch No } 6 . \\
\text { Edmonton, Alberta }\end{array}$ & 195 & 197 & $8 /$ no & $2 /$ no \\
\hline $\begin{array}{l}\text { Branch No } 8 . \\
\text { Ottawa, Ontario }\end{array}$ & 122 & 140 & $6 /$ yes & 32 / yes \\
\hline $\begin{array}{l}\text { Branch No 11, } \\
\text { Sarnia, Ontario. }\end{array}$ & 29 & 44 & $0 /$ no & $2 /$ no answer \\
\hline $\begin{array}{l}\text { Branch No } 13 . \\
\text { Winnipeg, } \\
\text { Manitoba }\end{array}$ & 332 & 336 & $3 /$ no answer & 150 / yes \\
\hline $\begin{array}{l}\text { Branch No } 17 . \\
\text { Regina, } \\
\text { Saskatchewan }\end{array}$ & 29 & 24 & $6 /$ no answer & $0 /$ no \\
\hline $\begin{array}{l}\text { Branch No } 20 . \\
\text { Toronto, Ontario. }\end{array}$ & 335 & 200 & $0 /$ no & $3 /$ yes \\
\hline $\begin{array}{l}\text { Branch No. } 25 \\
\text { Guelph, Ontario }\end{array}$ & 40 & 31 & $7 /$ yes & $0 /$ no \\
\hline $\begin{array}{l}\text { Branch No } 27 \\
\text { St. Catherine's, } \\
\text { Ontario }\end{array}$ & 115 & 118 & 42 / yes & $32 /$ yes \\
\hline TOTAL: & 1603 & 1505 & 84 & 222 (in reality 221 ) \\
\hline
\end{tabular}

Source: CPRI, SPK, Protokół Obrad XXI Walnego Zjazdu SPK w Kanadzie, 18-19.05.1985, Winnipeg, Manitoba, Zestawienie statystyczne ankiety na XXI Walny Zjazd SPK w 1985 roku; Ibid., Protokół z XXII Walnego Zjazdu SPK w Kanadzie, 16-18.05.2987, Regina Sask, Appendix 5: Zestawienie statystyczne ankiety na XXII Walny Zjazd SPK w 1987 roku. 
also board and lodgings and help in finding work after completion of the course ${ }^{55}$. The president of a small, approximately 50 person PCA branch in Lethbridge, Alberta wrote that: "...from November 1981 to April 1982 our branch gave to help the families which came from Austria and Germany CAD 840. Clothing and shoes as well" ${ }^{\prime 5}$.

Subsequent 1985 and 1987 surveys provided detailed data, as all branches were asked to send information about the number of immigrants sponsored by their members. As visible from the above mentioned figures, within the period of approximately five years combatants managed to sponsor 305 people altogether, which at the first glance does not seem to be a large number. Still, statistically every five ordinary members of the association sponsored one person. It should be also kept in mind that in 1980s most active PCA members were in their sixties and seventies, either retired or approaching retirement and plagued with various health problems. Sponsoring an immigrant was a long, time consuming process, requiring to face various administrative and organizational challenges i.e. filling in documentation, finding accommodation for the sponsored, helping them in work search, arranging school for the children, etc. These were the tasks that many veterans found difficult to take up, being elderly, ailing, frequently suspicious towards the newcomers and not willing to divert their resources from patriotic and commemorative events which they believed should form the core of PCA's activism.

Despite engagement, within their organizational capability, into the process of help for the new wave of immigrants from Poland, veterans remained quite hermetic and tightly knit group, which did not manage to attract the newcomers to join the association and get involved in veterans patriotic work. The old group of those who came to Canada during WWII or shortly after and the new Solidarity-wave immigrants had profound difficulties with overcoming mistrust and understanding their aims. Mutual understanding problems were openly voiced by the combatants during their general assembly held in 1983. In the opening address Association's president stated: "... it is difficult for us, the old emigrants to grasp what particular bigger or smaller groups of the newcomers represent and what they are fighting for between themselves. It is a fact that virtually every group publishes its own magazine or information leaflets. Never before has there been so many Polish titles in Toronto and generally in the Polish group. All these groups are in conflict, yet each

55 CPRI, SPK, Protokół z XX Walnego Zjazdu Delegatów SPK, 21-23.05.1983, Toronto, Ontario, Jan Trzcinski, V-Presez Zarządu Głównego SPK na Wschodnią Kanadę, Sprawozdanie za okres 1981/83, s.14.

56 CPRI, SPK, Protokół XX-go Walnego Zjazdu Stowarzyszenia Polskich Kombatantów w Kanadzie, 21-23 maj 1983, Toronto, Ontario, Sprawozdanie Prezesa Koła S.P.K. nr. 19, Lethbridge, pages unnumbered. 
one 'represents' Solidarity" ${ }^{17}$. Further in his speech conflicting interests of particular activists belonging to the new wave were pictured on the basis of Solidarity Information Office (Biuro Informacyjne Soliarności) in Toronto. "Already there are two offices, as the gentleman laid off from the original office established his own, rival one" ${ }^{58}$. The subsequent rhetorical question: "How will it end and who stands behind it?" points to the fears, deeply rooted in veterans' circles, that conflicts within the new group of immigrants were stirred up by communist agents who sneaked to Canada under the cover of political refugees. Majority of veterans perceived communism as the greatest threat which can hide everywhere, bringing "annihilation of the values worked out by the western civilizations and cruel enslavement of man"59.

In the above quoted speech President of the Polish Combatants' Association also pointed with indignation at bitter accusations made by the newcomers:

There are also those, who accuse us, the old, soldier Polonia, of idleness, even claiming that we came to Canada only to make money. They will now show us how to fight for Poland. Those who have never seen free Poland and tasted freedom only after their escape from the Polish People's Republic ${ }^{60}$.

The leaders of the Polish Combatants Association warned about crediting the representatives of the "new wave" with unconditional trust. PCA's president put it in the following words:

Restraint of the Polish Combatants' Association in taking a decisive stand towards the newly-arrived, young Poles, especially those who are very active politically, can turn out to be a very wise decision in the future. (...) I believe that we should wait until their position becomes clear. They should be given the possibility to convince us that we and they are ideologically unanimous. Consequently we should define to them the basics of our activism, which shall not be changed under any circumstances ... Our imponderabilia are: 1) rejection of communist, Trockyst, Leninist, Stalinist, Anarhist or whatever other facist-totalitarian theses and ideologies; 2. no recognition for communist dictatorship in Poland, and no contact with the regime whatsoever; 3. acknowledgement of legal continuity and authority of the president in Exile, i.e. President Edward Raczyński ${ }^{61}$.

${ }^{57}$ CPRI, SPK, Protokół XX-go Walnego Zjazdu Stowarzyszenia Polskich Kombatantów w Kanadzie, 21-23 maj 1983, Toronto, Ontario, Załącznik 14: Przemówienie Prezesa Zarządu SPK M. Szczecińskiego.

${ }^{58}$ Ibid., president Szczeciński probably referred to the activities of Zygmunt Przetakiewicz and his conflict with Canadian Polish Congress; see: Z. Przetakiewicz (2016), Spowiedź grzesznika z PAX-u, Solidarności i Andersena, Łomianki : LTW .

59 Sołtys E., Heydenkorn B. (1992), Trwanie w Walce..., p. 55.

${ }^{60}$ CPRI, SPK, Protokół XX-go Walnego Zjazdu Stowarzyszenia Polskich Kombatantów w Kanadzie, 21-23 maj 1983, Załącznik 14: Przemówienie Prezesa Zarządu SPK M. Szczecińskiego Toronto, Ontario.

61 Ibid. 
The authorities of PCA seemed to be aware that such an uncompromised attitude, and openly voiced mistrust can, and as can be seen from today's perspective, actually did discourage Solidarity-wave immigrants from joining combatants' circles and uniting efforts of these groups. Both the veterans and the newly arrived finally became victims of the atmosphere of suspicions and mistrust. Most of the Solidarity-wave immigrants who came to Canada in 1980s, fell into the category which was described by the combatants as “... quiet people, who want to settle and maybe join the already existing Polonia structures" ${ }^{2}$. They were by no means proponents of communist ideologies, nor supporters of Polish communist authorities. Their contacts with communist-ruled Poland were usually limited to relatives, friends and Solidarity activists. Thus, in theory both groups should have been able to find common platform, yet in practice it was not often the case. Veterans' reservation and suspiciousness was one of the reasons why immigrants from the "new wave" usually quickly gave up the attempts to join the circles of war and post-war immigration. The combatants, put off by the "... activism of those who are politicized" 63 were afraid that the disputes and disagreements of the newcomers can break unity of the veteran group as well.

This was not the only factor, however. Mutual understanding was also hampered by generation gap between the combatants (retired or approaching retirement) and the newly arrived (usually young adults in their thirties or early forties) and their totally different life experience. Veterans, in vast majority, were burdened with their traumatic war experience and remembered well the difficulties of the first years of their settlement in Canada. They have been struggling for a long time to build the position of PCA within Polish diaspora and in the Canadian society, to gather funds for purchase of associations' property and to finance various forms of patriotic activism. In their private lives they also had to put a lot of effort and work to achieve decent standard of living but nevertheless sometimes did not manage to attain the position their families had enjoyed in Poland before the war. Thus, they found little understanding for the newcomers from Polish People's Republic who could take advantage of various social programs sponsored by the state or private organizations. It was a general problem in relations between the "old" and "new" Polonia, especially that some new-wave immigrants actually did present high degree of resourcefulness in making the most of the assistance offered to them. Demanding attitude of some part of the newly arrived influenced the perception of the entire group, believed to present communism fostered attitude of dependency ${ }^{64}$.

62 Ibid.

63 Ibid.

${ }^{64}$ M. P. Erdmans (1998), Opposite Poles. Immigrants and Ethnics in Polish Chicago, 1979-1990. University Park: Pennsylvania State University Press, p. 122-123; J. Wojdon (2013), Polonia amerykańska a "Solidarność"..., p. 615-617. 
Ironically, lack of understanding between the "old" and "new" immigrants negatively affecting mutual relations of both groups in 1980s was not a new phenomenon. After WWII veterans and other displaced persons coming to Canada also had to cope with reservation of the immigrants who had come to that country at the end of $19^{\text {th }}$ and at the beginning of $20^{\text {th }}$ century. As the already established members of the society they did not fully understand expectations and needs combatants and their families who had faced the horrors of war. The conflict was also related to competition for leadership in Polish organizations in Canada as veterans challenged the old Polonia leaders. Unfortunately the experience of late 1940s and early 1950s probably faded away until 1980s. Old and new immigrants began functioning in parallel rather than together. In such situation both groups wasted certain opportunities which could open if they co-operated. Solidarity immigrants could not take advantage of veterans' organizational experience and capability, which would have been extremely valuable for them during their first years in the new country. Combatants, on the other hand, did not make use of the unique chance to attract new members into PCA and invigorate the whole community, decimated because of the natural demographic processes. In the result the scope of activism, organizational abilities and mobilization of both groups remained limited.

\section{References}

\section{Primary sources:}

Broda J.W. ed. (1971), Weterańskie listy, Ottawa: Biblioteczka Kieszonkowa

Heydenkorn B. ed. (1979), Memoirs of Polish Immigrants in Canada, Toronto: Canadian Polish Research Institute.

Heydenkorn B. ed. (1977), Pamiętniki imigrantów polskich w Kanadzie, Toronto: Canadian Polish Research Institute.

Jaroński Cz. (1977), W walce z przeciwnościami, in: Heydenkorn B. (ed.) Pamiętniki imigrantów polskich w Kanadzie, Toronto: Canadian Polish Research Institute, pp. 61-88.

Patalas K. ed. (2004), Providence Watching. Journeys from Wartorn Poland to the Canadian Prairies, Winnipeg: University of Manitoba Press.

Patalas K. ed. (1996), Przez boje, przez znoje, przez trud. Kombatanckie losy, Winnipeg: Stowarzyszenie Polskich Kombatantów w Kanadzie.

“SPK w Kanadzie” (quarterly of Polish Combatants' Association in Canada), years: 1971-1989.

The Canadian Polish Research Institute in Toronto (CPRI) - collection not catalogued.

- Stowarzyszenie Polskich Kombatantów (SPK)

- Kalendarzyk Kombatanta, years: 1949, 1965, 1972, 1979.

\section{Secondary sources:}

Bauer J. (1979), The Youngest Soldier, in: Heydenkorn B. (ed.) Memoirs of Polish Immigrants in Canada, Toronto: Canadian Polish Research Institute 1979, pp. 1-41.

Brzeziński T. (1988), Forty Years among Poles in Canada, in: Heydenkorn B. (ed.), Heritage and the Future. Essays on Poles in Canada, Toronto: Canadian Polish Research Institute, pp. 137-194. 
Canadian Response to the "Boat People" Refugee Crisis, http://www.thecanadianencyclopedia.ca.

Czterdzieści lat w służbie idei Stowarzyszenia Polskich Kombatantów. SPK w Kanadzie, Koło nr 6 Edmonton (1988), Edmonton: SPK w Kanadzie.

Dirks G.E. (1995), Controversy and Complexity: Canadian Immigration Policy During the 1980s, Monteral: McGill-Queen's University Press.

English J. (2009), Just Watch Me. The Life of Pierre Elliot Trudeau: 1968-2000, Toronto: Alfred Knopf Canada.

Erdmans M.P. (1998), Opposite Poles. Immigrants and Ethnics in Polish Chicago, 1979-1990. University Park: Pennsylvania State University Press.

Filek M., Koperski R. (1992), Stowarzyszenie Polskich Kombatantów w Australii (1950-1992), Adelaide: Zarząd Krajowy Stowarzyszenia Polskich Kombatantów w Australii.

Kardela P. (2013), Stowarzyszenie Polskich Kombatantów w Stanach Zjednoczonych wobec "Solidarności”, in: Jaworski P. , Kamiński Ł. (ed.), Świat wobec Solidarności, Warszawa: IPN, pp. 620-640.

Kardela P. (2015), Stowarzyszenie Polskich Kombatantów w Stanach Zjednoczonych w latach 1953-1990, Olsztyn-Białystok: Oddział IPN w Białymstoku.

Kelley N., Trebilcock M.J. (2010), Making of the Mosaic. A History of Canadian Immigration Policy, Toronto: University of Toronto Press.

Kędziora L. (2013), Polskie organizacje kombatanckie we Francji w latach 1945-1976, Warszawa: Difin.

Kelley N., Trebilcock M. J. (2010), Making of the Mosaic. A History of Canadian Immigration Policy, Toronto: University of Toronto Press.

Kogler R. (1995), The Polish Community in Canada, in: Sołtys E., Kogler R. (ed.) Half a Century of Canadian Polish Congress, Toronto: Canadian Polish Research Institute, pp. 299-332.

Kondracki T. (1996), Historia Stowarzyszenia Polskich Kombatantów w Wielkiej Brytanii, London: Zarząd Główny SPK w Wielkiej Brytanii.

Kondracki T. (2007), Polskie organizacje kombatanckie w Wielkiej Brytanii w latach 1945-1948, Warszawa: "Neriton" - Instytut Historii PAN.

Leitgeber W. (1995), Polski Korpus Przysposobienia i Rozmieszczenia w świetle dokumentów brytyjskich in: Klimaszewicz L. (ed.), Mobilizacja uchodźctwa do walki politycznej 1945-1990, London: Polskie Towarzystwo Naukowe na Obczyźnie.

Ostrowski J., Zarys historyczny Stowarzyszenia Polskich Kombatantów w Kanadzie, "SPK w Kanadzie" No. 2/74, April 1980, pp. 10-11.

Our History; http://www.legion.ca/who-we-are/what-we-do/our-history.

Polec P. (2013), Akceptacja i adaptacja do zmian: ruch "Solidarności" i solidarnościowi imigranci w społeczeństwie kanadyjskim i polsko-kanadyjskim w latach 1980-1991. Jaworski P., Kamiński Ł. (ed.), Świat wobec Solidarności, Warszawa: IPN, pp. 641-653.

Polish Ex-Servicemen in Great Britain (1948?), London: Information and Advice Bureau of the Polish Combatants' Association.

Przetakiewicz Z. (2016), Spowiedź grzesznika z PAX-u, Solidarności i Andersena, Łomianki: LTW.

Reczyńska A. (1997), Piętno wojny. Polonia kanadyjska wobec polskich problemów lat 1939-1945, Kraków: Nomos.

Reczyńska A. (1995), The Origins and the Beginnings of Canadian Polish Congress, in: Sołtys E., Kogler R. (ed.) Half a Century of Canadian Polish Congress, Toronto: Canadian Polish Research Institute, pp. 11-30. 
Soltys E., Heydenkorn B. (1992), Trwanie w walce - kulturowa analiza SPK w Kanadzie, Toronto: Canadian Polish Research Institute.

Soltys E., Klimaszewski K., Szczeciński M. (1997), Road to Freedom, Toronto: Polish Combatants Association in Canada.

SPK - Historia Federacji, http://parafiabradford.co.uk/SPK_history.pdf.

Wojdon J. (2013), Polonia amerykańska a "Solidarnośćc w latach 1980- 1989, in: Jaworski P., Kamiński Ł. (ed.) Świat wobec Solidarności, Warszawa: IPN, pp. 606-619.

Thornton M. (2000), The Domestic and International Dimensions of the Ressetlement of the Polish Ex-Srevicemen in Canada, 1943-1948, Queenston, Ontario: The Edwin Mellen Press. 